\title{
1. Conceptualising the relationship between revolutions and constitutions
}

\author{
Antoni Abat i Ninet
}

\section{$1.1 \quad$ INTRODUCTION}

The theoretical constructions of the phenomena of revolutions, first, and the understanding of constitutional revolutions as a subtype of revolution, second, has been a recurring theme in multiple disciplines of thought, as a sort of Nietzschean eternal return; when a new revolution occurs, new conceptualisations, question marks and arguments come by, and new rivers of ink flow. After the so-called 'Arab Spring', we are experiencing (in global terms) a 'contra revolutionary wave' at least from a constitutional perspective. The far-right authoritarianism, ethnic nationalism, Islamophobia and xenophobia is an example of a global revolution encompassing from Trump, Bolsonaro and the self-proclaimed presidents Áñez and Guaidó in the Americas, to Viktor Órban, Morawiecki, Salvini, Le Pen or the Spanish Vox in Europe to Modi or Prayut Cha in Asia.

Moreover, at the same time, massive popular protests or pre-revolutionary stages are rising in Catalonia, Hong Kong, Chile or the Gilets Jaunes in France. History continues its course. Whether these are revolutionary waves (Hannah Arendt, Colin J. Beck, Mark N. Katz) or the firsts steps of a global revolution (Rosa Luxemburg) is not an object of analysis of this chapter. However, if we consider these revolutionary movements as constitutional or potentially constitutionalised, it may help us in order to understand the relationship between both substantives and the ethical-value component that the consideration of revolution, a counterrevolution or a coup d'état, as a constitutional revolution has.

The relationship between revolutions and constitution has been analysed since the first political classifications in Plato, Aristotle, Cicero, Polybius, and later by Aquinas, Machiavelli, Rousseau and others. It is in these texts where we find the components of the new logos and the basis of the axiological foundation of the relationship between both concepts. Political systems, Politeia (constitution in the ancient sense) were related cyclically; the transit from 
a concrete political regime to another occurred through revolutions (revolvere), which means to roll back, to re-turn. Revolution was a political change, a constitutional evolution or involution within the circle of politics. We can wonder whether rolling back and returning is also the main feature of modern revolutions and counterrevolutions, especially when, in at first instance they do not succeed in the overthrowing of the political/constitutional system, but the revolutionary principles, purposes and aspirations remain dormant in important sectors of the civil society.

Ancient Athenians and Romans considered revolution inimical to the necessary stability that virtuous political systems require. A revolutionary change implies disruption, disorder, abrupt political changes and uncertainty, a totum revolutum that contradicts the understanding of a constitution as order ( $\tau \dot{\alpha} \xi 1 \zeta)$. A revolution not only contravenes stability, but it also breaches Phronesis (Prudence), an Aristotelian political virtue.

However, to revolt is necessary human behaviour as part of our human condition and when confronting injustice, tyranny or unjust law, revolution is a moral obligation (Thomas Aquinas) or a legal right (Alexander Hamilton). On the other hand, to revolt against God is always considered a sin; which, transposed into modern constitutionalism, is like to revolt against a valid and legitimate constitution, something legally, morally and reasonably unjustified.

This epistemic background presented constitution and revolution in a dichotomous antagonism, a perspective that was dominant since the emergence of modern constitutionalism. Undisputedly, the emergence of modern 'constitution' and constitutionalism has been generally linked with two revolutionary processes, the independence and foundation of the United States of America and the birth of the French Republic. This is widely acknowledged although we agree that this 'momentum' is the precise and concise instant to consider the emergence of modern constitutionalism. Alternatively, the implementation of modern constitutionalism can be understood as a continuum process, initiated in different places and times; ranging from the English 'Magna Carta', the 'Furs' in Catalonia, to the constitutions of the Northern Italy city-states or the Germanic concept system of 'Urdemokratie' applied in Northern Germany and Southern Scandinavia (Mogens Hansen).

US and French revolutionaries in the eighteenth century that mastered ancient political philosophy conceived their first constitutions as influenced by the thoughts of Plato, Aristotle, Cicero, Polybius and others. A constitution served to impose order, certainty and stability. Paradoxically, the first modern constitutions were at the same time revolutionary and legitimate; they exercised the right of revolution, as Alexander Hamilton defines it in the Federalist Paper number 28. Nonetheless, they were also counterrevolutionary, because they aimed to avoid future revolutions, even limiting the democratic principle and the role of the people in the new constitutional regimes. The debate 
between the Federalists (James Madison, Alexander Hamilton and Martin Jay) and the Antifederalists (Thomas Jefferson) on the role of the demos also evidences this extreme. As Andreas Kalyvas remarks, revolution is at the same time the beginning and the ending of a political process. What is a prima facie seems to be an epistemic antagonist relation between constitution, which means reason, order and the rule of law, and revolution, which implies disruption, disorder, and political and legal uncertainty; but this evolved into a more symbiotic relationship, since the origin of the two primary examples of modern constitutionalism were a result of revolutionary processes.

In the analyses of the epistemic conceptualisation of the relationship between revolutions and constitutions, the chapter goes further by analysing two nominal characterisations of this relation (revolutionary constitutions and constitutional revolutions) and the conceptual differences between them. By doing so, it addresses the semantic indeterminacy that affects the grammatical locution and epistemic construction of constitutional revolutions. Because of this lack of concreteness and indeterminacy, the chapter scrutinises if a coup d'état can be considered under some circumstances as a constitutional revolution, the relation between successful and failed revolutions with the process of constitutional accommodation, and the understanding of counterrevolutions as revolutions and their potential long-lasting constitutional influence.

The chapter goes further, analysing the symbiotic relation from two different philosophical perspectives, existentialism and phenomenology (eidetic). This philosophical analysis aims to measure whether the revolution has incorporated epistemologically constitutionalism, or if on the contrary, constitutions and revolutions still have a personal subjectivity (Martin Heidegger). From this philosophical prism, the chapter scrutinises whether the symbiotic relationship is obligate or facultative; and which sort of symbiosis is the one produced between revolution and constitution; mutualism, commensalism or parasitism.

\subsection{DEFINING AND DISTINGUISHING CONSTITUTIONAL REVOLUTIONS AND REVOLUTIONARY CONSTITUTIONS}

Lack of concreteness: There is no concrete definition of the constitutional revolution, nor the revolutionary constitution. This lack of concreteness is due to three different factors: firstly, the semantic indeterminacy (Jacques Derrida) that the concept of revolution compromises any of its variants or derivatives. Law and constitutions are an appeal to reason (Max Weber), and it is at this point where constitutions play a definitive role within the concept of revolution and in the revolutionary process in an epistemic sense. The role of constitutions in revolutions has overcome the mere grammatical function 
of complementing and adding information after the noun. In fact, since the triumph of modern constitutionalism around the world (Bruce Ackerman), there is a sort of symbiotic relationship between both components (revolutions and constitutions), or both components have been linked inexorably, also in an epistemological sense, forming a kind of synthesis.

This symbiosis (living together) and epistemological interaction are evidenced by the fact that since the American and French revolutionary experiences, there has been no revolution without a constitution at some point in the revolutionary process, or the pre-revolutionary constitution has been amended, interpreted or dismembered (Richard Albert) according to the revolutionary purposes. The fact is that 'modern constitutionalism' has been conditioned, factually and normatively (using Jürgen Habermas's nomenclature) by the revolutionary events that preceded the first modern constitutional texts. A relationship that was progressively consolidated by the constitutionalisation of each of the processes of decolonisation in the nineteenth and twentieth centuries; and also the appearance of constitutional charters in non-constitutional worlds (Nathan Brown), even in places where constitutions could be associated with domination and bourgeoisie (Communist regimes).

The holistic nature of constitution is manifested by the fact that there is no state in the world without a constitution. The fact that the UK, Israel and New Zealand do not have a unique and codified text named as constitution does not imply that they do not have constitutional, basic and primary rules developing the same functions that a constitution does; there is no state without a legal basis. The holistic nature of constitutions is also evidenced ipso facto by when the constitution covers all the legal acts of the state; nothing escapes to its empire, to its reason. The fact that the 'revolutionary' nature of a process always starts and ends in a constitutional process, opens in my understanding several epistemological questions on the role that both phenomena play in the relation.

A second element that determines the lack of concreteness of a definition for constitutional revolutions and revolutionary constitutions is the evaluative character that surrounds the consideration on whether a concrete constitution is revolutionary or a constitutional change can be considered as a revolution. The consideration of a constitution as revolutionary is a subjective act that conditions the collective imaginary and identity of a concrete political entity. As a matter of example, the definition of the Tarnovo Constitution, the first Bulgarian Constitution of 1879 (as Simeon Groysman details in Chapter 6), or the Mexican Constitution of 1917 as revolutionary charters aims to generate a concrete narrative conditioning political and constitutional purposes, symbols and values which are necessary to construct collective national identities.

Related to the second element that infuses a lack of concreteness to the terms revolutionary constitutions and constitutional revolutions, is who is 
entitled to decide whether a concrete revolt, coup d'état or constitutional text has a revolutionary nature. The answer to this question lies with the concept of sovereignty and the theory of deziosionismus. The one who decides that the Tarnovo Constitution was a revolutionary constitution is the sovereign at the concrete time to take the decision, meaning that at some time a constitution that is not considered as revolutionary changes and becomes revolutionary according to the political agenda of the sovereign. It can also happen in the opposite way; a revolutionary constitution with the course of time loses its pedigree.

A third element is the adaptation of each revolutionary wave to a concrete model of constitutional theory. After each revolutionary wave, the question of the relationship with constitutions reappears, and the position of both phenomena is revisited because the constitution juridifies the new beginning (Hannah Arendt) according to the purposes of the revolution. In other words, what is revolutionary today does not have to be tomorrow, and the same happens with the concept of constitution, which is complemented with prefix and suffix and adjectives (liberal) to be qualified.

A complementation evolved into a fusion according to a majoritarian academic opinion. Now a constitution implies necessarily some essential elements, such as the principle of separation of powers, the rule of law, and a charter on fundamental rights. According to this (idealistic) doctrine, to talk about illiberal, religious or authoritarian constitutionalism is a nonsense because it would breach the essence and nature of constitutionalism. Thus, Mexico, after a revolution, had a constitution but not constitutionalism, or despite the fact that there was a revolution in Russia in 1917, we cannot qualify the Soviet constitution of 1924 as such. In front of this idealistic doctrine of liberal constitutionalism, a realistic approach concludes the opposite (Günter Frankenberg, Roberto Gargarella, Duncan Kennedy). This debate opens new question marks on the definition of constitutional revolutions and revolutionary constitutions, and it serves as an opening to the next point of the section.

Distinguishing Revolutionary Constitution and Constitutional Revolutions. If one reads both locutions, the differences among them seem to be self-evident; each lexical unity has an own and a differentiated significance. Nevertheless, as happens with grammatical locutions, their meaning cannot be derived by a literal and strict interpretation of each of the component words, as a sum of the ordinary meaning of the components. The order of the search items plays a role in an epistemological sense and signifier and signified (Ferdinand de Saussure) also fluctuates.

Stressing the word constitutional instead of revolution does not alter the suppositio materialis, graphic or acoustic consistency of the terms, nor the parte objecti (Giorgio Agamben). In this sense, the conceptualisation offered is respectful to the etymology of the concepts constitutional (as an act of 
settling the most fundamental political principles of a state) and revolution (a revolt, sudden, radical or complete change). However, maybe the most appropriate nominal form for the concept of constitutional revolution offered by the authors will be altering the order of the nouns; the noun phrase has in 'constitution' its determinant syntagm.

To be clear, a constitutional revolution refers to an intra-legal systemic 'revolution', such as the cases of Israel or post-Khomeini Iran, or caused by constitutional adjudication, interpretation or amendment. The concept of constitutional revolutions is a white-collar one, thought and executed in bureaus and offices and not by the people in a violent revolt. On the other hand, a revolutionary constitution refers both to constitutions that came after a revolutionary process and to constitutions that can be qualified as revolutionary. This second acceptation is intimately linked with constitutional revolutions, in a sense that some doctrine uses both concepts indiscriminately.

In this sense, the Kelsenian theory on revolutions and Basic Norm deeply analysed in Part II of this book is a Gordian knot between two different phenomena, making it very difficult to distinguish them. A distinction with transcendental effects in terms of collective imaginary, constellations and constitutional narratives. A revolutionary constitution may point to this idealistic narrative, whereas a constitutional revolution targets a purely legal trend.

Formal and material elements to define revolutionary constitutions. Since the American and the French revolutionary experiences, revolutions are a form (Sheldon Wolin, Andrew Arato) of constitutional making. The form is here understood as a process but not as a warranty of legitimacy or legality (as legal positivism claims). I use the term form in the same way that is alluded to differentiate between formal and material constitution.

From a formal perspective, revolutionary constitutions are those constitutions that appear during a revolutionary process (transitional - constitutions) or as a consequence of a revolution. Therefore, the concept lies in the definition of a revolution.

The starting point for any contemporary 'theory' or account of revolution is Hannah Arendt's landmark essay 'On Revolution'. Arendt's essay is learned, allusive, suggestive - and not as transparent as we might like. The closest Arendt comes to offering a definition of the term revolution is this: 'only where change occurs in the sense of a new beginning, where violence is used to constitute an altogether different form of government, to bring about the formation of a new body politic, where liberation from oppression aims at least at the constitution of freedom can we speak of revolution'. ${ }^{1}$ Earlier, she writes,

Hannah Arendt, On Revolution (Penguin Group, 2006), 1. 
'crucial, then, to any understanding of revolution in the modern age is that the idea of freedom and the experience of a new beginning should coincide'. ${ }^{2}$

The thought here appears to be that revolutions require novelty and that the pre-revolutionary situation of the oppressed people is such that they can achieve novelty only by engaging in revolutionary violence. Therefore, the constitutional text that comes as a result of this revolutionary period can be defined as a revolutionary constitution in a formal sense.

However, not all the post-revolutionary constitutions are revolutionary charters; they might be in a formal sense because they are a result of a revolution, but if they do not accommodate the new beginning and the revolutionary values and principles, then the text is revolting nothing and it cannot be defined as revolutionary from a material sense. The material constitution to be considered revolutionary needs to adopt the purposes of the revolutionary as its purposes. Following Arendt's postulates, this constitution will need to include the formation of a new political body that aims to end the oppression and has the aspiration of freedom. Arendt did make 'establishing the conditions of freedom' a key element in her understanding of revolution, for example. Nevertheless, we observe that Arendt wrote not of 'social questions' but of 'the social question', by which she meant the question of the distribution of wealth in society.

At least some of the Colour Revolutions, and, more importantly, later events such as some of those during the Arab Spring, did implicate the Arendtian social question, as those suffering from the lack of essential material goods sought to overthrow kleptocrats (such as Ben Ali in Tunisia) who were leaching wealth away from the society generally. Furthermore, we think that revolutionary violence was central to Arendt's understanding of 'true' revolutions, so that - for her - movements that were 'largely non-violent' simply could not count as revolutionary. ${ }^{3}$ These requirements (social question, freedom, new beginning and violence) will exclude some of the most well-known and accepted revolutions. Could we consider the Iranian Revolution of 1979 as a revolution in Arendtian terms? What about Mussolini's fascist revolution (as he quotes in his autobiography) or Pinochet's coup d'état?

From the formal and material requirements pointed out, we can question whether the Constitution of Egypt of 2014 has changed the previous Constitution of 30 November 2012. Both constitutions are results of revolutionary and counterrevolutionary événements (José Ortega y Gasset, Paul

Ibid.

3.

Antoni Abat i Ninet and Mark Tushnet, The Arab Spring (Edward Elgar, 2015), 
Ricoeur). Then an apparent presumption is to think that both constitutional drafts involved significant changes in political and constitutional terms.

The Constitution of 2012 was passed by an Islamist party (Muslim Brotherhoods) that constitutionalised the main goals of the revolution (building up a democratic state, adherence to democratic principles, pluralism and a multiparty system). However, the previous constitution of 1971 in force under the presidency of Hosni Mubarak already stated that Egypt was a democratic state (Article 1), with a multiparty system (Article 5). Besides, the current Constitution of 2014 recognises these principles; democratic Republic (Article 1), with a political system based on political and partisan multiplicity (Article 5). Perhaps due to a sort of constitutional 'inertia' and despite the political measures that Mubarak, Morsi (potentially) and Sisi implemented, to eliminate these dispositions has a higher cost than to behave according to them.

The reading of Article 2 (as amended in 1980) of all these constitutional charters, the one related to the role of Islam and Sharia, a disposition exported by Egypt to the rest of the Arab world, can also enlighten the real change that these revolutions have caused in constitutional terms. Indeed, we can also define these dispositions as aspirational constitutionalism (Kim Lane Scheppele) or 'programmatic' constitutional declarations because of their null incidence in the daily life of citizens - using Richard Albert's wording 'Text and Reality' or 'mere nominal constitutional revolutions', as Jacobsohn coins these textual continuities in pre- and post-constitutional charters. The answer to these questions is related to a more essentialist and material analysis on constitutions.

An example of a revolutionary constitution in both senses is the Mexican Constitution of 1917, in a formal sense and despite that there is no clear understanding of whether the constitution was an ending point or the starting point of the revolutionary process. In the Mexican case, it is acknowledged that the constitution played a vital role in the multiple revolts, political, social and ideological movements and even civil wars that are conceptualised as 'the Mexican Revolution'. In a material sense, the constitution incorporated revolutionary elements, such as the social-labour constitutionalism, the recovery of national sovereignty and the principles of republican laicism.

Constitutional revolutions happen by very different means: activist constitutional interpretation, amendments, legal enactments or popular action. And, by multiple actors, courts, parliaments and the people. Scholars can apply the term 'constitutional revolution' only in retrospect, at which point one could wonder why doing so would matter anyway.

Formal and material elements to define constitutional revolutions. Even before Hannah Arendt, Hans Kelsen offered what Gary Jacobsohn describes as 'the standard instance' of a revolution: '[a] revolution occurs whenever the legal order of a community is nullified and replaced by a new order in an ille- 
gitimate way not prescribed by the first legal order' ${ }^{4}$ Richard Albert suggests a modification of Kelsen's formulation: revolutionary transformations occur through 'non-constitutional means', not illegitimate ones. ${ }^{5}$ Here the account is straightforwardly positivist. A regime's constitution prescribes rules for its amendment and even replacement. When those means are used, the transformation, no matter how substantial, does not count as a revolution. Only when revolutionaries act outside the existing constitution - whether in the streets or in the creation of their governing institutions that they simply take to be authoritative - can we say that a revolution has occurred. This formulation avoids the difficulty we have identified with Kelsen's version. ${ }^{6}$

A constitutional revolution is a legal/constitutional action or omission (enactment, interpretation or amendment) that causes a revolution in the realm of constitutionalism. There is no need for violence (Gary J. Jacobsohn and Yaniv Roznai), nor a direct intervention of the people. However, Bruce Ackerman's theory of constitutional moments and Richard Albert's theory of dismemberments can in some cases be considered as constitutional revolutions and include the will and action of the people. The social question (Hannah Arendt) is not a requirement of constitutional revolutions, but the 'new beginning', at least in the constitutional sphere, is the qualifying requirement of this sort of constitution. A new beginning that does not need to coincide with the experience of freedom to qualify some constitutional breaks and changes as revolutionary. ${ }^{7}$

The specialised doctrine has provided constitutional revolutions with their logos and ethos. They do not need to be defined necessarily as Kelsenian because the revolutionary constitutional change, break or rupture can be performed following the pre-established constitutional channels. How do we address the limits and attributions of the 'pouvoir constituent dérive' and the permeable meaning of 'bloc de constitutionnalite' within this new conceptualisation? The answer may be to qualify as revolutionary and/or merely constitutional some of the revolutions labelled by the authors.

Formal elements of constitutional revolutions. There is no concrete form to assess whether a constitutional amendment, rupture or extensive interpretation can be qualified as revolutionary. Somehow, the basic Aristotelian syllogistic principle, $\mathrm{P}$ (premise) then $\mathrm{Q}$ (consequence) is altered, and from the Q we

4 Gary J. Jacobsohn, 'Theorising the Constitutional Revolution' (2014) 2 Journal of Law and Courts 1.

5 Richard Albert, 'Democratic Revolutions' (unpublished manuscript) offers a thorough survey of the role theorists of revolution have given violence.

6 Abat i Ninet and Tushnet (note 3) 7.

7 Gary J. Jacobsohn, and Yaniv Roznai, Constitutional Revolution (Yale University Press, 2020). 
obtain the P. The experience shows ${ }^{8}$ that the constitutional changes performed by the Supreme Court in Israel made a constitutional revolution. Therefore, the relevance of the form is relative; what matters is the result, the material (constitution) aspect. The epistemic conceptualisation of constitutional revolution is teleological and descriptive.

Gary J. Jacobsohn and Yaniv Roznai remark:

a constitutional revolution can occur as a governing set of rules and principles establishing a constitutional order based on a political revolution that overturned a previous regime, or as a major change in the constitutional order emerging within the parameters of an extant constitutional setting and without any, or at least without significant, violence or illegality. ${ }^{9}$

This definition overcomes the widely accepted definition of constitutional revolution (Kelsen) that consisted of the establishment of a new constitutional order after the illegal overturning of a previous order. To them, a legal or a-legal overturning can also be considered as revolutionary. They do not consider plain violence as a requirement of a constitutional revolution. Violence is understood in a narrow sense, physical, or, as they characterise, thunder and lightning. However, they are not considering the inner symbolic violence that can be associated with constitutionalism: violence as vis - vindicatio, or symbolic violence that affects the social Psyche-Polis, the 'public soul' and causes individuals to adjust their behaviour consciously or unconsciously to the constitutional order. Alternatively, as Austin Sarat and Thomas R. Kearns pose it, violence as a fact and a metaphor is integral to the constitution of modern law, and that law is a creature of both literal violence, and imaginings and threats of force, disorder and pain. ${ }^{10}$

Material elements of constitutional revolutions. The material trend of a constitutional revolution lies quasi-exclusively in the concept of change, a significant change affecting the set of rules and principles that found the constitutional order and with substantive constitutive significance. If the polity undergoes a substantial reorientation in constitutional practice, it is enough to define this trend as a constitutional revolution. Accordingly, a coup d'état can be qualified as a constitutional revolution if it transforms the constitutional order substantially. Pinochet made a constitutional revolution. The admission of a coup d'état as a constitutional revolution happens because of the finalist

Ibid.

Ibid. 21.

10 A. Sarat and T.R. Kearns, Law's Violence (University of Michigan Press, 1993), 1. 
character of the definition, and the absence of other requirements (democratic involvement, a search for freedom or the social question).

\subsection{UNSUCCESSFUL REVOLUTIONS AND COUNTERREVOLUTIONS}

Unsuccessful Constitutional Revolutions. One of the best-known masterpieces of Frédéric Chopin is his Étude Op.10, No. 12 in C minor, the 'Revolutionary Étude' devoted to the Polish failed revolution against the Russian empire in 1830-1831. With this universal work of art, Chopin immortalised these events and evidenced the strong emphasis on the political potential of the arts (Herbert Marcuse). This universal magnum opus serves as an allegory on the need to analyse failed revolutions. The analysis of unsuccessful revolutions helps to understand the role that constitutions and constitutionalism play in the revolutionary process. It also determines that in the current understanding of constitutional revolutions, as happened with Kelsen's definition of revolutions, there is an identification of legality, legitimacy and rupture. ${ }^{11}$

What happens when a revolution fails, what happens with its values, effects and principles? They vanish and die, or they remain dormant until a new revolution occurs or a constitutional revolution accommodates this revolutionary background. Are these values part of a universal concept of revolution? The response to these questions depends on the concrete casuistry, context and circumstances of each revolution.

The Hungarian failed revolution of 1956, the Tibetan in 1956, Paris May 1968, the Prague Spring or the Chiapas (Mexico) uprising in 1994 are unsuccessful revolutions, which, even though they did not achieve their immediate political goal, some of their claims, principles and values lasted and conditioned future revolutions. There is no doubt about the universal effects of May 1968 and the political repercussions that the Hungarian revolution of 1956 and later the Prague Spring had in neighbouring countries of the Warsaw pact and even in Polish Solidarność. Therefore, it can be argued that the Polish revolution of 1989 is somehow related to the revolutionary events that occurred in Hungary and Prague some decades before.

This same revolutionary connectivity can be argued when we define the revolutionary waves, such as the Colour Revolution or the so-called Arab Spring. The ousting of Milośević in 2000 in Yugoslavia is related to the overthrow of Eduard Shevardnadze in 2003 in Georgia, the defeat of Askar Akayev in Kirgizstan in 2005, and with the successful and failed revolutions

11 Andrew Arato, Post Sovereign Constitution Making, Learning and Legitimacy (Oxford University Press, 2016), 108. 
in the Middle East and North Africa (MENA) region. The label of successful and unsuccessful loses its sense if we consider revolution as an international or not domestic phenomenon if we understand that revolutions, failed. Success is part of the same reality that may always return to the political agenda of a determinate country.

In the case of the Zapatista revolution in Chiapas, after the military defeat of the Ejército Zapatista Liberación Nacional (EZLN), the movement became identified with the struggle for indigenous rights in Mexico, and put on the political and constitutional agenda from 1994 to 2000 significant constitutional reform to constitutionally recognise Indian Autonomy and Indian Rights. If the constitutional change caused by the revolution in Chiapas has substantive constitutive significance (under dispute), can we define the EZLN's revolution in Chiapas as a failed revolution but as a successful constitutional revolution? The question shreds of evidence that the definition of a constitutional (reason, certainty and pretended objectivity) revolution, as successful or unsuccessful has strong elements of subjectivity.

In his work on revolutionary constitutions, Bruce Ackerman affirms that he only analyses successful revolutionary constitutions. ${ }^{12}$ However, he includes among the cases under study the case of Israel, as a revolution without an express constitutionalisation. Gary J. Jacobsohn and Yaniv Roznai also include Israel among their case studies, as a process of constitutional revolution through adjudication.

In the case of Israel, the Declaration of the Establishment of the State of Israel of 14 May 1948 incorporated an express mandate to adopt a constitutional text by the Elective Constituent Assembly before October 1948. More than 70 years later, this mandate has not materialised. David Ben Gurion, a fierce supporter of the adoption of a constitutional text for his state, summarised the three significant reasons that made it impossible to reach the consensus necessary to complete the constitutional process: the frontal rejection of a constitutional text by the Orthodox community; the possible mutability of the state borders; and, finally, the constitutional anchoring of the country's Arab minority. Signs that shed more light on the 'revolutionary' process in the State of Israel, and the need to understand the tremendous vicissitudes and uncertainties that the new state faced in 1948.

It can be stated that some of the controversial issues generated by the approval by the Knesset (Israeli Parliament) of the Basic Law of the Jewish Nation-State of 19 July 2018 are closely related to the issues that made it challenging to write a constitution for the State of Israel from the first moment

12 Bruce Ackerman, Revolutionary Constitutions, Charismatic Leadership and the Rule of Law (Harvard University Press, 2019). 
in 1948. This constitutional experience can be defined as an unsuccessful constitutional revolution. From this failure, and throughout constitutional adjudication (Gary J. Jacobsohn and Yaniv Roznai), revolutionary legalism (Bruce Ackerman) or judicial activism, Israel has faced a constitutional revolution.

Counterrevolutions. Counterrevolutions are revolutions, and constitutional counterrevolutions are constitutional revolutions too. This identification can be built upon Hegelian dialectics, where revolutions are thesis, counterrevolutions are the antithesis and synthesis will be a concept in between both poles. Counterrevolutions have been a universal accompaniment of all revolutions. The term 'counterrevolution' refers to a policy of trying to reverse a revolution, and, by extension, to policies designed to prevent revolutionary movements that have already gained some momentum from coming to power. It denotes, therefore, both reversal or overthrow, and what has been referred to, variously, as suppression and containment. ${ }^{13}$

In this sense, it is of interest to analyse the phenomenon of counterrevolutions when conceptualising the relation between revolutions and constitutions, especially, if a coup d'état can be considered as a constitutional revolution; when there is no need to include the people, or when the concept of revolution is no longer linked necessarily with the Arendtian 'social question'. In this sense, Marcuse's words accusing the Western world of organising a counterrevolution may resonate with force. ${ }^{14}$

A theory of constitutional revolutions is not complete without the presence of the counterrevolutionary aspect. There is no 'theory of counterrevolutionary constitution', there is no mention of counterrevolutionary constitutions, nor of constitutional counterrevolutions. Alfred Meusel describes a counterrevolution as 'an attempt to reverse the transformations effected in a revolution; its success signalises the triumph of the upper class, which has been endangered and temporarily displaced by the revolution'. ${ }^{15}$

From this definition, we can scrutinise whether some of the examples coined as constitutional revolutions and revolutionary constitutions are indeed counterrevolutionary processes. The questioning is even more justified in cases of constitutional revolutions orchestrated from the judiciary bench, intellectual upper class or political and economic castes and elites.

Bruce Ackerman poses it for the cases where regime change occurs because of an elite construction and without the pressure of a massive popular upris-

13 F. Halliday, Revolution and World Politics, The Rise and fall of the Sixth Great Power (Duke University Press, 1999), 207.

14 H. Marcuse, Counterrevolution and Revolt (Beacon Press, 1972).

15 A. Meusel, 'Revolution and Counter-Revolution', Encyclopedia of the Social Sciences, XVIII, 368. 
ing. ${ }^{16}$ Where the political establishment remains in control of the situation, making strategic concessions that take the wind out of the sails of the insurgent movement, this generates a constitution that will typically claim to speak in the name of the People. However, the elites have not been propelled into existence by a mass movement of citizen activists who have struggled in the People's name. ${ }^{17}$

Ackerman follows by using the Spanish transition as a revealing example. The price of this elitist constitutional revolution or counterrevolutionary constitution, is that in Spain there was never a Commission for Truth and Reconciliation; elites remained in power, the country still has more than one hundred thousand mass graves, and a pre-constitutional law of amnesty and a full-stop and 'due obedience' law bars any possibility of democratic regeneration. It is an attempt of forced oblivion imposed on future generations of Spaniards.

In 1972, Marcuse wrote as an example of counterrevolution that Black militants pay with their lives: Malcolm X, Martin Luther King, Fred Hampton, George Jackson. ${ }^{18}$ Four decades later, they are still paying with their lives, hundreds such as George Floyd, and the counterrevolutionary discourse is still installed in the White House and other public stakeholders to stop any revolutionary movement. This evidences that failed revolutions can come back to the political arena in future revolutionary waves, and that the counterrevolutionary will react against these movements using all available means, including constitutions and its empire.

\subsection{SYMBIOSIS}

The relationship between revolution and constitution can be qualified as a symbiosis, especially since the appearance of modern constitutionalism during the final stages of the eighteenth century, and the ensuing triumph of constitutionalism around the world. After two centuries of epistemic interaction of both symbionts, a progressive evolution of this living together of two unlike phenomena can be observed. What was a facultative relationship, where revolutions and constitutions could generally occur independently, has been transformed into a more obligatory one, where one of the symbionts (revolution) depends on the other (constitution) to last, to 'survive'.

Due to a legal positivistic and reactionary discourse, without a constitution its legal, political, rational and epistemic empire - revolutions are incomplete,

Ackerman (note 12), 6 .

Ibid.

8 Marcuse (note 14), 1. 
and they risk being forgotten, expulsed of collective processes of memory and identity of the political entity, and of the universe (for those who consider revolution as an international and interconnected phenomenon). If there is no constitution accommodating the purposes, principles and values of a revolution, the latter does not exist as such; it then becomes a failed or unsuccessful revolution, a revolt and uprising, but not a revolution because political revolutions need constitutions to succeed.

On the other hand, a constitution without a revolutionary character, an epic of sacrifice, risks being a text without 'soul'. That is why the Preamble of all French constitutions refer to a Declaration promulgated more than a century ago, or other constitutions refer to epic and revolutionary episodes of the past. Therefore, it can be argued that from an existentialist perspective, which considers that the fundamental question in being is its existence and not its essence, revolutions have an obligated symbiotic relationship with constitutions; a relation that is based on mutualism where both symbionts obtain reciprocal benefits.

An alternative perspective to this symbiotic nature is to present the possibilities of an eidetic of the relationship and by using the phenomenology as methodology. This analysis allows the evaluation on whether the concept of revolution has incorporated epistemologically constitutionalism, or if on the contrary, constitutions and revolutions still have a personal subjectivity (Martin Heidegger).

Although there are not many examples of Edmund Husserl's application of eidetic variation to relationships, nothing seems to exclude them from the possibility of eidetic analyses. ${ }^{19}$ An eidetic of the 'revolution-constitution' relationship must necessarily be of the type (Typus) of this relationship. The eidetic of the relationship considers both elements, revolution and constitution, as objects subjected to any possible predication; as when we say, 'Revolutions and constitutions are taking place' or as when we affirm, 'The relationship between revolutions and constitutions is being subjected to mutations'.$^{20}$

From the eidetic variation of relationships, (a) the relationship between revolution and constitution can only maintain its relational character when both poles have the form of personal subjectivity, and (b) the relationship revolution-constitution is based on a sharing of contents that should not instrumentalise the relationship. The first question that emerges is if, under the new conceptualisation of constitutional revolutions, both poles maintain this

19 On the eidetic relation, see J. González Guardiola, 'Cap a una eidètica de la relació ensenyament-aprenentatge', in 2019, Col.loquis de Vic XXIII, pp. 173-85 (in Catalan).

20 Ibid. 
personal subjectivity. In my understanding, a definition that considers a revolution as non-violent, not popular, not social and without an idea of freedom, does not necessarily limit the subjectivity and identity of both poles of the relationship. However, if the term revolution is limited to a constitutional change or a constitutional dismemberment, the personal subjectivity ends. Concerning the second question (instrumentalisation), under the definition of constitutional revolution described above, what content is shared by the concept of constitution to the relationship? There is an instrumentalisation of the concept of revolution that mutates the symbiotic relationship.

Accordingly, the relation between revolution and constitution, if it is qualified as symbiotic, will be an obligate one. The symbiosis is commensalism, if we ponder that the concept of revolution is not epistemologically subjugated to the concept of constitution. Alternatively, it is parasitic, if we believe that the concept of revolution has been denaturalised and instrumentalised by the concept of constitution.

\subsection{CONCLUSION}

This chapter scrutinises the epistemic relationship between revolution and constitution, a relationship that has been evolving in the course of history, and found a transcendental and existential moment in the eighteenth century. The birth of modern constitutionalism is a consequence of revolutions. However, this dependence is not mutual, and it is entirely possible to have a constitution without a revolution.

However, and due to the holistic nature of constitutionalism, this initial trend varied, and the predominant position in the relationship has been anchored in the constitutional side. According to the dominant doctrine, there is no political revolution without constitution. It is in this sense that a new concept of revolution arises, the constitutional revolution; where the new universe of the revolution is the realm of constitutionalism and its agents.

The denaturalisation of the concept of revolution opens multiple epistemic questions, some of them are existential, such as is it a coup d'état, a counterrevolution, or a constitutional revolution? Can a judge or a bench of judges perform a coup d'état and at the same time be considered as constitutional revolutionaries? What is the role and rule of the people in constitutional revolutions enforced by non-democratic actors? Is it necessary for a previous democratic authorisation to legitimate some of these revolutions? On the other hand, will an a posteriori rule of recognition (Hart) and the habit of obedience be enough to consider as legitimate these constitutional revolutions? Who legitimates these officials (Hart) - judges (Joseph Raz and Christopher Kutz) or lawyers (Alexander de Tocqueville) - to have such a power? 